\title{
Effectiveness of Incubation Centres in Creating Sustainable Businesses in Zimbabwe
}

\author{
Ms Ntombifikile Ndebele ${ }^{1 *}$, MBA, Dr Fainos Chinjova, Ph.D ${ }^{1}$ \\ ${ }^{\mathrm{T}}$ National University of Science and Technology; Corner Gwanda Road and Cecil Avenue; Bulawayo; Zimbabwe \\ *Corresponding Author \\ Ms Ntombifikile Ndebele
}

\author{
Article History \\ Received: 04.03.2021 \\ Accepted: 22.03.2021 \\ Published: 29.03.2021
}

\begin{abstract}
The aim of the study was to analyse and evaluate the effectiveness of the incubation centres in Zimbabwe in creating sustainable businesses. The study was motivated by the fact that there is evidence of the fact that there is a very high rate of closure of SMEs in Zimbabwe despite the provision of business incubation services in the country. The study used a mixed research approach in which a case study research design was applied to gather data. A case study design was chosen because it allowed a lot of primary data to be gathered using multiple techniques. Data was gathered from a sample of 16 business incubation trainers and 4 school administrators who were purposively selected using snowball sampling technique. Key findings were that business incubator centres were not effective in creating sustainable businesses because they faced a number of challenges which includes inadequate skills and knowledge of incubators, lack of in-house seed funds, lack of support from stakeholders, lack of skilled entrepreneurs and professionals. The study gave concluded by giving recommendations to the Government of Zimbabwe through the Ministry of Women Affairs as well as to the Business Incubation Centres.
\end{abstract}

Keywords: BUSINESS INCUBATION; SMEs.

\section{INTRODUCTION}

The introduction of business incubation centres has contributed to the improved rate of success in establishing sustainable businesses in most developed countries [1]. Business incubators are seen globally as an essential tool for the creation and development of Small to Medium Enterprises [2]. Likewise, the concept of business incubators was adopted by both the Government of Zimbabwe through the establishment of incubation centres at State Universities, Polytechnic colleges and the private sector in order to facilitate growth of sustainable local small to medium industries. However, some evidence claim failure rates of SMEs in Zimbabwe despite the provision of business incubation services hence motivated this study to investigate and establish the effectiveness of business incubation centres in creating sustainable SMEs in Bulawayo Metropolitan province [3, 4].

\section{BACKGROUND TO THE STUDY}

The productive sector capacity utilisation in Zimbabwe is expected to decline to 27 percent by the end of 2020 , down from 36 percent realised in 2019 and 48 percent in 2018 [5]. Zimbabwe's economy has declined rapidly to a point where the country ranks among the poorest economic performers in the region due to poor quality Small to Medium Enterprises [6]. Bulawayo, once the industrial hub of Zimbabwe has also been hit hard as Small to Medium Enterprises has either been closed or abandoned [7]. Chigundu [8] reported that government will be rolling out business incubation programs to help unlock potential in the country's Small to Medium Enterprises (SMEs) sector.

Business incubation is a concept that describes a business development process meant to grow successful and sustainable entrepreneurial ventures that will contribute to the health and wealth of local, regional and national economies [9]. Business incubators and innovation hubs are a very practical tool for bringing the best ideas to life and to a point of scale and commercialisation [3]. Incubators are also the tools via which knowledge is disseminated from the knowledge-generating systems such as the universities and research institutions into the economic pool of society [10]. Business incubators facilitate entrepreneurial processes where ideas are shaped into successful commercial businesses [11]. According to Grimaldi and Grandi [12] incubators help newly established firms through supporting services and the

Copyright (C) 2021 The Author(s): This is an open-access article distributed under the terms of the Creative Commons Attribution 4.0 International License (CC BY-NC 4.0) which permits unrestricted use, distribution, and reproduction in any medium for noncommercial use provided the original author and source are credited. 
critical and important assistance they give to start-ups. A study by Olkiewicz, Wolniak, Eva-Grebski and Olkiewicz [13] revealed that the introduction of incubation centres in North-eastern Pennsylvania and the Slack Region of Poland resulted in the growth of sustainable local small to medium industries.

According to Obaji, Onyemerela and Olugu [14] business incubation is a programme targeted at keeping young entrepreneurial firms warm and safe through an array of support services until they are strong and sufficiently mature to move out of the incubator and flourish on their own. This incubation process nurtures the development of beginning and emerging small to Medium Enterprises (SMEs) through a range of resources and services [8]. Thus, the primary goal of a business incubator is to produce sustainable SMEs that will leave the incubation program as a self-supporting entrepreneur compared to the start-up period when they are most vulnerable [15]. Therefore, businesses incubators seek to raise the success rate of SMEs significantly Lose and Tengeh [16]. In other words, business incubators are recognised as inventive instruments that are increasingly becoming important in fostering the promotion of competitive and sustainable SMEs [17]. However, some business analysts claim failure rates of SMEs in developing countries as high as 60 percent in the first five years, and some anecdotal evidence in South Africa would even suggest it may reach up to 80 $\%$ despite the provision of business incubation services hence motivated this study to investigate and establish the effectiveness of business incubation centres in creating sustainable SMEs in Bulawayo Metropolitan province [18-20].

In both developed and developing economies, SMEs must be encouraged and supported to flourish by the business incubators. Business incubators and innovation hubs are a very practical tool for bringing the best ideas to SMEs' life and commercialisation. Thus, the primary reason for a business incubation centre is to create successful enterprises and to connect and network them within their business community [21]. With the help of the government, business incubation centres must build the capacity of local Small to Medium Entrepreneurs through training; provide seed funding to get them started and thereafter sustaining them [3]. More importantly, a well-run business incubation centre should be able to source various funding options for the proven businesses, allowing them to scale through funds for better and bigger equipment, wholesale purchases of raw material and oiling through working capital and order finance for effective creation of sustainable SMEs [3]. Business Incubation unit provides development of entrepreneurship programmes and courses, enterprise development in place of industrial attachment, offering business and financial advisory services, mentorship programmes, entrepreneurial research output and networking with funding organisations [8]. To establish sustainable SMEs, the business incubation programme must host internal competitions and field its' people in national and international ones to give them necessary exposure [3]. It is the interest of this study to find out how business incubators facilitate the establishment of sustainable SMES in order to evaluate the effectiveness of business incubation centres in creating sustainable SMEs in Bulawayo Metropolitan province.

In South Africa, township business incubation centres face numerous challenges in the creation of sustainable SMEs that include lack of managerial skills, financial challenges, lack of credit, and lack of access to markets, usable technology, low production, and inadequate institutional support [18]. In Indonesia, some business incubators fail to establish sustainable SMEs due to lack of management skills, lack of marketing support and financial access [7]. Business incubators in West Bank were not able to help small enterprises to overcome their problems due to weak linkages to the knowledge base and external support like universities, professional and skilled companies, banks [22]. The above findings from international researchers influenced this study to assess whether Zimbabwean business incubators are experiencing similar challenges in order to evaluate the effectiveness of business incubation centres in creating sustainable SMEs in Bulawayo Metropolitan province.

Business incubation centres in Zimbabwe continue to churn out graduates every year that cannot start their SMEs due to limited entrepreneurial opportunities and skills to engage in self-employment [3, 8, 4]. Thus, there is lack of skills by entrepreneur graduates to utilize the potential available resources, under performance of enterprises especially small-scale agriculture and high rate of business failure in Zimbabwe [8]. Small to Medium Enterprises firms dominate both developed and developing economies in terms of self-employment and number of SMEs but their full potential remains untapped despite their graduation from Business incubators [23]. SMEs in Zimbabwe make up 94\% of the country's self-business population but only contribute $15 \%$ to the country's economy due to a high failure rate during the first 5 years [4]. SMEs in Zimbabwe are not expanding and do not survive for more than 5 years [1]. Impliedly, this study seeks to explore challenges faced by Business incubators in facilitating sustainable SMEs in order to evaluate the effectiveness of business incubation centres in creating sustainable SMEs in Bulawayo Metropolitan province.

\section{STATEMENT OF THE PROBLEM}

Despite the application of the business incubation concept in Bulawayo, there is no evidence on the increase of sustainable Small and Medium Enterprises. Economic development in Bulawayo is affected by the poor quality of Small to Medium Enterprises despite a mandatory support from the business incubation programs [3]. There is lack of skills by graduate entrepreneurs to utilize the potential available resources, and under performance of graduate enterprises especially small-scale agriculture as well as high rate of business failure in Zimbabwe [8]. Business incubation centres in 
Zimbabwe continue to churn out graduates every year that cannot start their SMEs due to limited entrepreneurial opportunities and skills to engage in self-employment [8]. Moreover, small to medium businesses in Zimbabwe make up $94 \%$ of the country's business population but only contribute $15 \%$ to the country's economy due to a high failure rate during the first 5 years [4]. Thus, small to medium businesses in Zimbabwe are not expanding and do not survive for more than 5 years [1]. Therefore, persistence of high failure rate and poor quality Small to Medium Enterprises despite a mandatory support from the business incubation programs motivated this study to assess and evaluate the effectiveness of business incubation centres in creating sustainable SMEs in Bulawayo Metropolitan province [3].

\section{PURPOSE OF THE STUDY}

The purpose of this study was to analyse and evaluate the effectiveness of incubation centres in creating sustainable SMEs in Bulawayo Province in order to come up with recommendations to address their challenges in mentoring and developing these businesses so as to promote the economic growth of the province.

\section{RESEARCH OBJECTIVES \\ 5.1 Primary Objective}

To assess the effectiveness of business incubation centres in establishing sustainable SMEs in the Bulawayo Province

\subsection{Secondary Objectives}

The main objective will be supported by the following sub-objectives:

- To determine the facilitation of business incubators on the establishment of sustainable SMEs in Bulawayo province.

- To explore challenges faced by business incubators in facilitating the establishment of sustainable SMEs in Bulawayo province.

- To establish suggested strategies to improve effective business incubator facilitation of sustainable SMEs.

\section{RESEARCH QUESTIONS}

\subsection{Main Research Question}

How effective are business incubation centres in creating sustainable SMEs in Bulawayo Province?

\subsection{Sub-questions}

- How Business incubators facilitate the establishment of sustainable SMES?

- What are challenges faced by Business incubators in facilitating the establishment of sustainable SMEs?

- Which are the suggested strategies to improve effective Business incubator facilitation of sustainable SMEs?

\section{DELIMITATIONS OF THE STUDY}

The study will be confined to Bulawayo Business Incubation centres only. It looks into the effectiveness of business incubation centres in establishing sustainable SMEs in the Bulawayo Province. The research approach that informs the conduct and writing of this study is mixed methods.

\section{REVIEW OF RELATED LITERATURE 8.1 Conceptual framework}

Conceptual framework focuses on giving an understanding or conceptualisation of effective business incubation with a potential of creating sustainable SMEs. In this study, conceptual framework to present the picture of effective business incubation was based on various researchers and business specialists' perceptions. In simple terms, the traditional business incubator is a microenvironment with a small management team that provides physical workspace, shared office facilities, counselling, information, training and access to finance and professional services in one affordable package [24]. The business incubation process has been described in many different ways. Hackett and Dilts [25] described it as a 'black box' with unknown activities occurring within. Alternative descriptions rely on gardening terms such as germination, as a metaphor for the activities within an incubator to create sustainable SMEs [17].

Globally, the process of business incubation is quite simple: a prospective tenant/incubatee is interview for their suitability for business incubation and they move into an office or other space inside the incubator from which they will operate their business [25]. The business incubator provides assistance in the form of office services, management advice, mentoring, networking and general business assistance [12]. The incubator may also be able to provide funding assistance to grow the venture. After a period of time, (likely to be at least three years), the business graduates from the incubator into the surrounding business economy [26]. The concurrent issue of small business failure prompted business incubators to be a focus for economic development programs [27], particularly as they have been found to reduce the failure of start-up small businesses, create jobs, and wealth in a regional economy [26]. 


\subsection{Theoretical Framework}

The engagement of a theoretical framework that allows a broader insight of incubation centres' experiences in the Zimbabwe is therefore vital to establish the effectiveness of incubation centres in creating sustainable SMEs in Bulawayo Province [28]. Therefore, this study was informed by Hackett and Dilts's real options-driven theory of business incubation which focuses on creating sustainable SMEs [29]. Hackett and Dilts concluded that real optionsdriven theory is most applicable to the process of business incubation to develop sustainable SMES [28]. According to real options-driven theory of incubation, a real option is created through an initial investment decision followed by subsequent investment decision(s) to be done by graduated SMEs in the entrepreneurship environment [30]. In an incubator context, a real options perspective view incubatee selection as the creation of an option, and subsequent resource infusions and monitoring and assistance as option exercises to create and develop sustainable SMEs [28, 31].

The rationale for the use of Hackett and Dilts' real options-driven framework in this study is from the understanding that the theory offers the best available lens for capturing the operational setting and underlying logic that drives the incubation process of selection, monitoring and assistance, and resource infusion vis-a-vis incubatees [26]. This implies that the effectiveness of incubation centres in creating sustainable SMEs in Bulawayo Province cannot be achieved in isolation but in relation to their real option of selection, monitoring and assistance, and resource infusion to establish qualified and self-sustained SMEs.

The evaluation of the effectiveness of incubation centres in creating sustainable SMEs will be guided by the real options driven theory of business incubation, which is describe incubation process as business incubation performance [31]. This is measured in terms of incubatee growth and financial performance at the time of the incubator exit [28]. Therefore, it is a function of the incubator's ability, development capabilities and resources to create options through the selection of weak-but-promising intermediate potential firms for admission to the incubator, and to exercise those options through mentoring and counselling, and the infusion of the resources while containing the cost of potential terminal option failure [30].

According to Kemp the real options driven theory of business incubation further express an incubator's function

as:

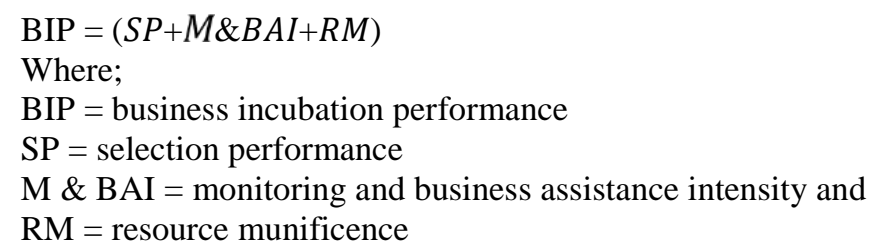

In other words, the theoretical framework argues that the performance success of a business incubator is a product of three factors: the selection of the correct tenants, the quality of the incubator assistance and the level of financial resources to deliver services to tenants as well as networks. The real options driven framework of business incubation goes further to widen the scope of this study by guiding the researcher to assess the effectiveness of incubation centres in creating sustainable SMEs in Bulawayo Province. The real options driven framework evidently reveals the functions that form the business incubation framework of creating sustainable SMEs. These options driven form the nucleus of the framework to assist this study to establish the effectiveness of the effectiveness of incubation centres in creating sustainable SMEs in Bulawayo Province.

This framework explains that the real options of business incubation centers signify a business incubation performance (reflecting the effectiveness of incubation centres in creating sustainable SMEs). If there is a gap in any of the business incubation performance (unavailability of incubator assistance, financial resources to deliver services, space, as well as networks) the result will be a short circuit (challenges faced by business incubators in facilitating the establishment of sustainable SMEs) and will show that creation of suatainable SMEs is not significantly effective. The assumption here is that, an occurrence of a short circuit at any stage of the business incubation performance would result in a major disruption of business incubation process towards creating of sustainable SMEs in Bulawayo province. Thus, any challenge or problem (major disruption) experienced faced by business incubators in facilitating the establishment of sustainable SMEs would evaluate the effectiveness of incubation centres in creating sustainable SMEs in Bulawayo Province.

\subsection{Gap analysis}

Various qualitative and quantitative studies in most of developed countries discovered that with an aid from the government, business incubators utilized educational and information centres (such as universities, schools, colleges and post offices) as co-working spaces for their potential entrepreneurs and innovators to establish sustainable SMEs in the 
community hence motivated this study to seek to assess how business incubators in Bulawayo facilitate the establishment of sustainable SMEs in order to evaluate their effectiveness in creating sustainable SMEs [28, 32, 18, 33].

International studies, particularly in developing countries, admitted that business incubation centres experienced challenges such as failure to provide production space and technology facilities, geographical factors, economic and political factors as well as poor linkages with external network in establishing sustainable SMEs while local reviewed literature is silent on that issue thereby motivating this study to assess whether the above challenges are common within the Zimbabwean business incubation centres or not in order to evaluate the effectiveness of business incubation centres in creating sustainable SMEs in Bulawayo Metropolitan province [34, 19, 22, 35, 36].

\section{RESEARCH METHODOLOGY}

\subsection{Research Approach}

This study used mixed methods approach to explore and evaluate the effectiveness of business incubation centres in creating sustainable SMEs in Bulawayo Metropolitan province. When using the mixed methods approach, the researcher mixes both quantitative approach that collects numeric data (numbers) and qualitative approach that collects text (words) in a single study [37]. The researchers opted for a mixed methods approach to influence methods of data collection that created an opportunity to record and understand the participants' views regarding effectiveness of business incubation centres in creating sustainable SMEs in Bulawayo Metropolitan province on their own terms and lived experiences. This approach offered the researchers the best chance of addressing the specific research questions. In using the mixed methods approach, the researchers ensured triangulation of both quantitative and qualitative methods and data sources in a single study [37]. It also ensured the convergence and cooperation of results from the different methods on the same phenomenon $[38,39]$.

\subsection{Research Design}

Research design or method is a blueprint for conducting the mixed methods research study in such a way that maximum control would be exercised over challenges that could interfere with the trustworthiness of the research findings [40]. It is a road map that determines the most appropriate route to take when carrying out mixed methods research study [41]. Therefore, the case study research design was considered the most appropriate approach to employ in this study because it provided a systematic way to collect data or multiple perspectives rooted in a specific context [31].

The researchers also opted for case study as an action plan because it allowed a lot of primary data to be gathered using multiple techniques. With case study design, all collected evidences on the effectiveness of business incubation centres in creating sustainable SMEs in Bulawayo Metropolitan province were interpreted to arrive at the best possible responses to the research question(s). As a result, this design allowed the researchers to gain a sharpened understanding of the effectiveness of business incubation centres in creating sustainable SMEs in Bulawayo Metropolitan province.

\subsection{Population}

The approximate total target population of this study was 75 potential participants. The business incubation trainers were used in this study because they are experiencing the incubation process and creation of sustainable SMEs in Bulawayo Metropolitan Province. They were in a position to give the required information regarding the effectiveness of business incubation centres in creating sustainable SMEs in Bulawayo Metropolitan Province. Principals and HODs as business incubation administrators are directly involved with the supervision and monitoring of the facilitation and creation of sustainable SMEs in Bulawayo Metropolitan province. They are also suitable potential participants of this study because of being rich data source of information relevant for describing the effectiveness of business incubation centres in creating sustainable SMEs in Bulawayo Metropolitan province.

\subsection{Sample}

In this study the chosen sample was made up of four business incubation centres in Bulawayo province with 16 business incubation trainers and 4 school administrators (Principals and HODs). Thus, the chosen sample was made up of purposively snowballed selected business incubation trainers who voluntarily responded to the open and closed-ended questionnaires. The researchers also used data saturation principle to obtain a sample from business incubation administrator who voluntarily participated in the interviews. Therefore, the sample size of 20 snowballed participants was determined by data saturation where no new or relevant information seems to image [38, 39]. This study was limited to a small group of business incubation trainers and school administrators (Principals and HODs) which was acceptable and typical of mixed methods approach which was highly qualitative. These participants were therefore the small group of knowledgeable and informative business incubation trainers and school administrators (Principals and HODs) in Bulawayo province. In this regard, McMillan and Schumacher [42] maintain that mixed method highly in qualitative researchers investigate in-depth small, distinct groups as the researchers were concerned with understanding the social phenomena from the participants' perspective. 


\subsection{Sampling procedure}

In this study, snowball sampling method was used. According to Creswell [43] and Neuman [44], snowball sampling is a procedure for building a sample based on individuals or groups judged as being appropriate and rich in information for the study that is underway. Maree [45] states that the snowball sampling only follows the rule that the participants should be individuals who are rich in information related to the phenomenon under study $[39,43,46]$.

\subsection{Research instruments}

Data generating instruments in this study included the open and closed-ended questionnaire and interviews aiming to obtain information on the effectiveness of business incubation centres in creating sustainable SMEs in Bulawayo Metropolitan province.

\subsection{Data collection procedure}

The researcher was the main data generating instrument who administered questionnaires to the selected business incubation trainers from four chosen business incubation centres in Bulawayo province. The researchers first sought and secured clearance from NUST, Ministry of Women affairs and SMEs, business incubation centres, administrators and trainers in Bulawayo province.

\section{DATA ANALYSIS}

In this empirical study, interim analysis approach propounded by Miles and Huberman in Johnson and Christensen [39] was employed throughout the study for data processing. The approach involved the cyclical process of collecting data, analysing data, collecting additional data, analysing those data and so on until the researcher of this study ran out of data resources or data saturation. Interim analysis helped the researcher to collect data over an extended time period until a successfully deeper understood of the participants' opinions on the effectiveness of business incubation centres in creating sustainable SMEs in Bulawayo Metropolitan province was done. Maoming technique, which refers to reflective notes written by researchers recording ideas on emerging concepts, themes and patterns generated during data processing were, used [39]. The data generated were constantly reviewed, categorised, labelled and analysed to form themes and patterns based on sub-research questions which guided the current study. The qualitative data generated were effectively analysed through transcription, segmenting, and coding as recommended by [39]. Therefore, memos or reflective notes of interviews with business incubation administrators and open-ended questionnaires of the business incubation trainers from Bulawayo province was transformed into typed text which was a more usable form for further qualitative data analysis.

As prescribed by Creswell [47], the researchers asked the interview participants to check and verify (member checking) what had been documented and that their views were correctly interpreted to establish trustworthiness of data for better data analysis. Segmenting involves grouping the data into meaningful analytical units [39]. This was done by carefully reading the transcribed data from interviews and open and closed-ended questionnaires line by line deriving the specific meaning which was important for this empirical study. A meaningful segment was bracketed in the form of a word, phrase, single sentence or a paragraph to address the sub-research questions which guided the current study.

\section{RESEARCH FINDINGS AND DISCUSSIONS}

\subsection{Extent to which business incubators facilitate the establishment of sustainable SMES}

Results from the study revealed that most of the business incubation centres in Bulawayo failed to provide incubates with educational centres like universities, colleges and industries as co-working spaces to create qualified, skilled and sustainable SMES. Findings reflected and concluded that business incubation centers in Bulawayo Metropolitan province did not provide incubates with shared, subsidized rental space, equipment and office infrastructure until they were qualified. Findings from the empirical study presented and concluded that Bulawayo Metropolitan province business incubation centres used their own entrepreneurship for the incubates to practice as employees not as entrepreneurs instead of providing them an opportunity to run a business during their training. Results from the study indicated and concluded that Bulawayo Metropolitan province business incubates were not linked to financial institutions, educational institutions, industries, donors, NGO and technical expertise to facilitate their sustainable SMEs. Findings revealed that Bulawayo Metropolitan province business incubation centres did not operate an outreach program, visiting Start-up SMEs to provide incubates with ongoing business advisory service, monitoring and assistance until incubates were qualified to stand on their own. The study disclosed that business incubation centres in Bulawayo Metropolitan province failed to provide incubates with financial services such as seed loan as a facilitation strategy to create sustainable SMEs, leaving them to source capital for themselves. Therefore, the results of the study concluded that business incubation centres were not significantly effective in establishing sustainable SMEs in the Bulawayo Province.

\subsection{Challenges faced by Business incubators in facilitating the establishment of sustainable SMEs}

The findings concluded that inadequate skills and knowledge, lack of in-house seed funds for incubates and lack of consistent support from stakeholders such as government, financial institutions, and educational institutions, 
professional and skilled entrepreneurs were some of the major challenges affected the effective facilitation of establishing sustainable SMEs in Bulawayo Metropolitan province. Results from the study that poor linkages with external network and lack of government support were other major challenge faced by business incubators in facilitating the establishment of sustainable SMEs in Bulawayo Metropolitan Province. Therefore, the findings from the study concluded that business incubation centres were not significantly effective in establishing sustainable SMEs in the Bulawayo Province.

\subsection{Suggested strategies to improve effective Business incubator facilitation of sustainable SMEs}

Results from the study concluded with a suggestion that:

- Business Incubators in Bulawayo need to empower trainers with business incubation knowledge and skills development through workshops, staff development and going to universities for them to effectively facilitate the creation of sustainable SMEs.

- There is a need for Business incubators to follow the Business incubation policy which provide a framework for systematic approach in their research and incubation processes in order to provide the most innovative ideas to them incubates hence effective establishment of sustainable SMEs.

- There is a need for local city council to empower Business incubation centres with enough space or big stands to provide incubates working spaces within premises on subsidized rent to ensure the success of incubated startups.

- There is need for business incubation centres to link the incubates with financial institutions, academic sector like local universities, polytechnic collages and industrial expertise to improve effective Business incubator facilitation of sustainable SMEs.

- There is need for the government, through the Ministry of women affairs and SMEs, to link business incubators with scientific institutions, international research centres, financial institutions, universities and entrepreneur expertise to engineer the facilitation of sustainable SMEs in the country.

- There is need for the government to support business incubator's initiatives with grants, soft loans and inputs to empower the effective facilitation of creating sustainable SMEs.

\section{RECOMMENDATIONS}

Based on the conclusions of the study, the following recommendations were made:

\subsection{To Government}

- The study recommended that there is need for the government, through the Ministry of Women Affairs and SMEs, to link business incubators with scientific institutions, international research centres, financial institutions, polytechnic colleges, universities and entrepreneur expertise to engineer the facilitation of sustainable SMEs in the country.

- The study also recommended that there is need for the government to support business incubator's initiatives with grants, soft loans and inputs to empower the effective facilitation of creating sustainable SMEs.

\subsection{To Business Incubation centers}

- The study recommended that Business Incubators need to empower trainers with business incubation knowledge and skills development through workshops, staff development and going to universities for them to effectively facilitate the creation of sustainable SMEs.

- This empirical study recommended that there is a need for Business incubators to follow the Business incubation policy which provide a framework for systematic approach in their research and incubation processes in order to provide the most innovative ideas to incubates, hence effective establishment of sustainable SMEs.

- Finally, the study recommended that there is a need for local city council to empower Business incubation centres with enough space or big stands to provide incubates with working spaces within premises on subsidized rent to ensure the success of incubated start-ups hence effective facilitation of sustainable SMEs.

\section{REFERENCE}

1. Amoah, R., Samuel, N. B., \& Richardson, A. M. K. (2014). Accounting practices of SMES in Sunyani: An investigative study of record keeping for performance measurement. International Journal of Research in Economics and Social Sciences, 4(7), 21-35. http://www.indianjournals.com

2. Lose, T., Tengeh, R.K. (2015). The Sustainability and Challenges of Business Incubators in the Western Cape Province, South Africa, Sustainability, 7(10), 14345-14357.

3. Mubaiwa, K. M. (2020). Why small business incubation matters. Herald. Harare Mutambi, J., Byaruhanga, J. K., Trojer, L and Buhwezi, K. B. (2010) Research on the State of Business Incubation Systems in Different Countries: Lessons for Uganda African Journal of Science, Technology, Innovation and Development, 2(2); 190 - 214.

4. Sibanda, B. (2016). Sustainability of Small Businesses in Zimbabwe during the First 5 Years. Doctoral Thesis, Walden University. 
5. Chimhenga, S. (2014). An assessment of the factors affecting the implementation of inclusive education for children with learning disabilities in Zimbabwean primary schools. UNISA: South Africa.

6. Al-Mubaraki, H. M., \& Busler, M (2017). Challenges and opportunities of innovation and incubators as a tool for knowledge-based economy, Journal of Innovation and Entrepreneurship, ISSN 2192-5372, Springer, Heidelberg, 6(15), 1-18, http://dx.doi.org/10.1186/s13731-017-0075-y

7. Bismala, L, Andriany, D., \& Siregar, G. (2020). Development strategy analysis of technology business incubator in small medium enterprises accompaniment. Journal of critical reviews. http://dx.doi.org/10.31838/jcr.07.01.39

8. Barugahara, F., Maumbe, B., \& Nzaro, R (2017). Developing a Business Incubator Model for an Entrepreneurial University: The Case of Bindura University of Science Education. ACRID DOI 10.4108/eai.20-6-2017.2270037

9. Cullen, M., Calitz, A., \& Chandler, L. (2014). Business incubation in the Eastern Cape: a case study. International Journal for Innovation Education and Research, 2(5), 76-89.

10. Klofsten, M., Bank, N., \& Bienkowska, D. (2016). The role of incubators in supporting sustainable entrepreneurship. SHIFT: Berlin, Germany.

11. Carayannis, E. G., \& Von Zedtwitz, M. (2005). Architecting gloCal (global-local), real-virtual incubator networks (G-RVINs) as catalysts and accelerators of entrepreneurship in transitioning and developing economies: lessons learned and best practices from current development and business incubation practices. Technovation, 25(2), 95-110.

12. Grimaldi, R., \& Grandi, A. (2005). Business incubators and new venture creation: an assessment of incubating models. Technovation, 25(2), 111-121.

13. Olkiewicz, M., Wolniak, R., Eva-Grebski, M., \& Olkiewicz, A. (2018). Comparative analysis of the impact of the business incubator center on the economic sustainable development of regions in USA and Poland. Sustainability, 11(1), 1-22.

14. Obaji, N.O., Onyemerela, C., Olugu, M. U. (2015). Entrepreneurship and Business Incubation Programme: The Sure Couple. Int. J. Sci., Tech. and Mgt. 4, 1627-1633

15. Barrow, C. (2001). Incubators: A Realist's Guide to the World's New Business Accelerators. New York: John Wiley and Sons

16. Lose. T., Maziriri, E. T., \& Madinga, W. (2016). Assessing the impact of incubation programme to small and medium enterprises development in the Western Cape Province of South Africa. International Journal of Small Business and Entrepreneurship Research, 4(4), 16-29,

17. Hanadi, M. A. M., \& Busler, M. (2010). Business Incubators: Findings from a Worldwide Survey, and Guidance for the GCC States. Global Business Review, 11, 1, 23-29

18. Dubihlela, J., \& Van Schaikwyk, P. J. (2014). Small Business Incubation and the Entrepreneurial Business Environment in South Africa: A Theoretical Perspective. Mediterranean Journal of Social Sciences, 5(23)

19. Skaik, M. Z. (2013). The Role of Business Incubators in Achieving the Sustainable Development in the Gaza Strip. Case Study: The Business and Technology Incubator at IUG. Thesis, The Islamic University of Gaza.

20. Davies, M. (2009). Mixed-use Incubator Handbook: A Start-up Guide for Incubator Developers, in fo Dev.

21. Totterman, H., Sten, J. (2005). Start-ups: Business Incubation and Social Capital. Int. Small Busi. J. 5, 487--511

22. Qawasmi, M. (2010). "The Reality of Business Incubators and their Role in Supporting Small Enterprises in the West Bank"

23. Zindiye, S.,Chiliya, N., \& Masocha, R. (2012). The impact of Government and other Institutions' support on the Performance of Small and Medium Enterprises in the Manufacturing Sector in Harare, Zimbabwe. Int. J. Buss. Mgt. Eco. Res., 3(6),2012,655-667

24. Costa-David, J., Malan, J., Lalkaka, R., (2002). Improving Business Incubator Performance through Benchmarking and Evaluation: 16th International Conference on Business Incubation National Business Incubation Association, Canada.

25. Hackett, S. M., \& Dilts, D. M. (2008). Inside the black box of business incubation: Study B - scale assessment, model refinement and incubation outcomes. Journal of Technology Transfer, 33, 439-471.

26. Hackett, S. M., \& Dilts, D. M. (2004b). A systematic review of business incubation research. Journal of Technology Transfer, 29(1), 55-82.

27. Burns, N., \& Grove, S. K. (2009). The practice of nursing research. Missouri: Saunders Elsevier.

28. Al-Mubaraki, H.M. (2013). The Effect of Business Incubation in Developing Countries. Euro. J. Busi. Innov. Res.1, $19--25$

29. Hackett, S. M. (2004). Real options and the option to incubate: An exploratory study of the process of business incubation. http://ssrn.com/abstract=1260438

30. Hackett, S. M., \& Dilts, D. M. (2004a). A real options-driven theory of business incubation. Journal of Technology Transfer, 29(1), 41-54.

31. Ritchie, J. Lewis, J. (2003). Qualitative research practice: A guide for social science students and researchers. London: Sage.

32. Stefanovic, M., Devedzic, G., \& Eric, M. (2008). Incubators in Developing Countries: Development Perspectives, International Journal for Quality Research, 2(3), 157-163. 
33. Bubou, G., M., \& Okrigwe, N.F. (2011). Fostering Technological Entrepreneurship for SocioEconomic Development: A Case for Technology Incubation in Bayelsa State, Nigeria, Journal of Sustainable Development, (4)6.

34. Tembe, F. (2018). Business incubators and SMMEs performance in South Africa. Thesis, University of the Witwatersrand. South Africa.

35. InfoDev. (2010). Global Practice in Incubation Policy Development and Implementation. South Africa Incubation. Country Case Study. Washington: http://www.infodev.org/infodev-files/resource/

36. Adegbite, O. (2001). Business Incubators and Small Enterprise Development: The Nigerian Experience, Small Business Economics, 17(3), 157-166.

37. Tichapondwa, S. M., Focke, W. W., Del Fabbro, O., \& Muller, E. (2013). Suppressing hydrogen evolution by aqueous silicon powder dispersions by controlled silicon surface oxidation. Propellants, Explosives, Pyrotechnics, 38(1), 48-55.

38. Creswell, J. W. (2007). Qualitative enquiry and research design: choosing among five approaches. $2^{\text {nd }}$ Ed. London: Sage.

39. Johnson, R. B., \& Onwuegbuzie, A. J. (2004). Mixed methods research: A research paradigm whose time has come. Educational researcher, 33(7), 14-26.

40. Creswell, J. W. (2003). Research design: Qualitative, quantitative and mixed approaches. $2^{\text {nd }}$ Ed Thousand Oaks: Sage.

41. Yin, R. K. (2009). Case Study Research: Design and Methods $4^{\text {th }}$ Ed. Los Angeles, C A: Sage.

42. McMillan, J. H., \& Schumacher, S. (2010). Research in education: evidence based enquiry. $7^{\text {th }}$ Ed. New Jersey: Pearson Education.

43. Creswell, J. W. (2013). Qualitative enquiry and research design: choosing among five approaches. $4^{\text {th }}$ Ed. London: Sage.

44. Neuman, W. L. (2006). Social research methods: qualitative and quantitative approaches. $6^{\text {th }}$ Ed. Toronto: Allyn and Bacon.

45. Maree, K. (2007). First steps in research. Pretoria: Van Schaik.

46. Struwig, F. W., \& Stead, G. B. (2001). Planning, Designing and Reporting Research. Cape Town: Masker Miller Longman (Pvt) Ltd.

47. Creswell, J. W. (2009). Research Design: Qualitative, Quantitative and Mixed Approaches. $3^{\text {rd }}$ Ed. Los Angeles. Sage Publications, Inc.

Citation: Ntombifikile Ndebele \& Fainos Chinjova (2021). Effectiveness of Incubation Centres in Creating Sustainable Businesses in Zimbabwe. South Asian Res J Agri Fish, 3(2), 17-25. 